\title{
TPR/NTRK1 Fusion Gene TRKT2
}

National Cancer Institute

\section{Source}

National Cancer Institute. TPR/NTRK1 Fusion Gene TRKT2. NCI Thesaurus. Code C99859.

A fusion gene $(\sim 4.5 \mathrm{~kb})$ that results from an inversion of the $\mathrm{q}$ arm of chromosome 1 that fuses 3073 nucleotides of the 5' part of the TPR gene to 1412 nucleotides from the 3' portion of the NTRK1 gene. This rearrangement is associated with papillary thyroid carcinoma. 